\title{
POTENSI RENDAMAN TSUNAMI DI WILAYAH LEBAK BANTEN
}

\author{
POTENTIAL TSUNAMI INUNDATIONIN LEBAK COASTAL OF BANTEN PROVINCE
}

\author{
Dedi Sugianto ${ }^{1,2)}$, I Wayan Nurjaya ${ }^{2)}$, Nyoman MN Natih ${ }^{2)}$ dan Wahyu W Pandoe ${ }^{3)}$ \\ ${ }^{1)}$ Pusat Gempa Bumi dan Tsunami BMKG, Jl. Angkasa I no 2 Kemayoran Jakarta 10720 \\ ${ }^{2}$ Departemen Ilmu dan Teknologi Kelautan Fakultas Perikanan dan Ilmu Kelautan, Institut Pertanian Bogor \\ ${ }^{3)}$ Pusat Teknologi Rekayasa Industri Maritim BPPT, Jl. Kawasan Puspitek Serpong, Tangerang Selatan 15314 \\ e-mail : dedibmg@gmail.com
}

Diterima tanggal: 22 Januari 2017 ; diterima seletah perbaikan: 14 maret 2017 ; Disetujui tanggal: 12 April 2017

\begin{abstract}
ABSTRAK
Studi ini mengkaji tentang potensi bahaya tsunami yang terjadi di pesisir pantai Lebak Banten. Zona subduksi di selatan Jawa merupakan wilayah yang menarik untuk dipelajari, karena di dalam zona ini berpotensi terjadi gempabumi yang dapat menyebabkan terjadinya tsunami. Wilayah Kabupaten Lebak Banten terletak di bagian selatan Jawa Barat dan berhadapan dengan sumber tsunami di Samudra Hindia. Tujuan penelitian ini adalah untuk mengetahui run-up yang terjadi akibat tsunami dari gempabumi di celah kegempaan (seismic gap) sekitar Palung Jawa, menghitung waktu tempuh yang diperlukan oleh tsunami tersebut hingga mencapai wilayah pesisir Lebak Banten dan mengetahui potensi rendaman di wilayah tersebut. Metode yang digunakan dalam penelitian ini meliputi simulasi skenario tsunami dari gempa bumi dengan kekuatan Mw 8,7 dengan menggunakan model TUNAMI-N2 dan analisis hasil keluaran model. Berdasarkan analisis hasil simulasi menggunakan TUNAMI-N2 tersebut, run-up yang dapat terjadi akibat tsunami dari gempa bumi di celah kegempaan sekitar Palung Jawa umumnya mengikuti pola topografi ketinggian wilayah. Waktu tempuh yang diperlukan oleh gelombang tsunami pertama hingga mencapai wilayah pesisir Lebak berkisar antara 15 hingga 17 menit. Potensi rendaman tsunami wilayah pesisir Lebak jika terjadi gempabumi di celah kegempaan sekitar Palung Jawa pada umumnya terdapat pada kategori sangat berbahaya mengingat tinggi run-up dapat mencapai lebih dari 3 meter dari permukaan dan jarak maksimum rendaman mencapai 1,7 km dari garis pantai, dengan luas genangan 1271,34 ha.
\end{abstract}

Kata kunci: Rendaman, tsunami, Labak Banten, zona subduksi, run-up, TUNAMI-N2.

\section{ABSTRACT}

This study examines the potential of tsunami hazards that could occur in coastal areas of Lebak Banten. The subduction zone in the south of Java is an interesting area to be studied, because this is an earthquake zone which may potentially cause a tsunami. Lebak Banten region is located in southern part of West Java and dealing with the source of tsunami in Indian Ocean. The purpose of this study was to determine run-up of tsunami wave that may occur as a result of earthquakes in seismic gap around Java Trench. Tsunami Traveling time is also computed, in order to know potential inundation of coastal areas in Lebak Banten. The method used in this study include field surveys, tsunami scenarios for earthquake the magnitudo Mw 8.7, simulation using TUNAMI-N2 models and results analysis from model output. Based on analysis of simulation results, run-up that occur as result of tsunami caused by earthquakes in seismic gap of the Java Trench generally follow the pattern of topographic elevations. Travel time required by first tsunami wave to reach coastal areas of Lebak ranged from 15 to 17 minutes. Inundation over coastal areas of Lebak generally are in very dangerous category considering the maximum tsunami height can reach more than 3 meters above sea level. The maximum distance inundationis $1.7 \mathrm{~km}$ from coastline to the shore, with total inundation area of 1271,34 ha.

Keywords: Inundation, tsunami, Lebak Banten, subduction zone, run-up,TUNAMI-N2. 


\section{PENDAHULUAN}

Sebagai salah satu dari beberapa negara yang terletak di kawasan Zona Seismic Asia Tenggara, Indonesia adalah salah satu negara yang paling aktifitas seismicnya dan merupakan teraktif di dunia. Indonesia dikelilingi oleh lempeng Indo-Australia dan Pelat Laut Filipina yang meretas di bawah lempeng Eurasia, dengan lima pulau besar dan beberapa semenanjung, Indonesia telah mengalami ribuan gempa bumi dan ratusan tsunami pada rentang empat ratus tahun terakhir (Aydan, 2008). Sumatera dan Jawa adalah dua pulau yang paling rentan dampak tsunami karena terletak langsung di depan Lempeng Indo-Australia. Kabupaten Lebak merupakan salah satu kabupaten yang terletak di wilayah Provinsi Banten. Secara administratif Kabupaten Lebak berbatasan dengan Kabupaten Serang dan Kabupaten Tangerang di utara, Kabupaten Pandeglang di barat, Provinsi Jawa Barat di timur dan berbatasan dengan Samudra Hindia di selatan. Wilayah Kabupaten Lebak memiliki garis pantai yang berhadapan langsung dengan Samudra Hindia, yang secara geologis merupakan daerah tepian benua aktif karena merupakan pertemuan antara lempeng samudra Indo-Australia dan lempeng benua Eurasia yang dicirikan dengan aktivitas kegempaan yang sangat tinggi. Sebagian besar gempa bumi berpusat di dasar laut, dan beberapa diantaranya pernah menimbulkan gelombang tsunami (gempa bumi Banyuwangi 1994 dan gempa bumi Pangandaran 2006). Sejarah telah mencatat bahwa pada tahun 1883 terjadi letusan gunung api Krakatau yang efeknya menimbulkan gelombang tsunami yang menimbulkan kerusakan infrastruktur cukup parah dan menimbulkan korban tewas sekitar 35.000 jiwa. Wilayah ini juga digolongkan sebagai daerah aktif dipandang dari sudut kegempaan, serta banyak struktur geologi.

Pulau Sumatra dan Jawa terletak pada bagian tepi selatan Sunda $\operatorname{arc}$. Sunda arc dimulai dari laut Andaman utara Aceh - Sumatra - Jawa sampai ke pulau Sumbawa di selatan sebagai island arc systems (Mulyana, 2006). Perubahan arah subduksi dari lempeng Indo-Australia kearah lempeng Eurasia bersifat normal terhadap Jawa membentuk trench Jawa dan oblique ke arah Sumatra membentuk trench Sumatra, lihat Gambar 1.

Berdasarkan kondisi tersebut, daerah penelitian sangat menarik untuk dikaji potensi bahayanya, terutama dalam hal tsunami. Hasil penelitian yang dikombinasikan dengan pemodelan tsunami menghasilkan perkiraan dampak landasan tsunami di kawasan pantai daerah penelitian. Data ini diharapkan dapat dipergunakan sebagai dasar dan informasi dalam perencanaan dan pengembangan kawasan pantai di wilayah Kabupaten Lebak. Selain itu untuk meningkatkan kewaspadaan masyarakat terhadap kemungkinan terjadinya tsunami yang dapat terjadi setiap saat, sehingga dapat memperkecil dampak (mitigasi) dan mengantisipasi langkah-langkah penyelamatan diri dengan memanfaatkan potensi alami yang dimiliki kawasan pantai.

Berdasarkan asumsi ini sebagian besar pantai barat dan pesisir selatan Banten yaitu Kec. Malingping karena topografinya yang relatif landai, adalah daerah rawan tsunami. Selama ini BMKG memberikan informasi dini adanya ancaman tsunami jika terjadi gempa

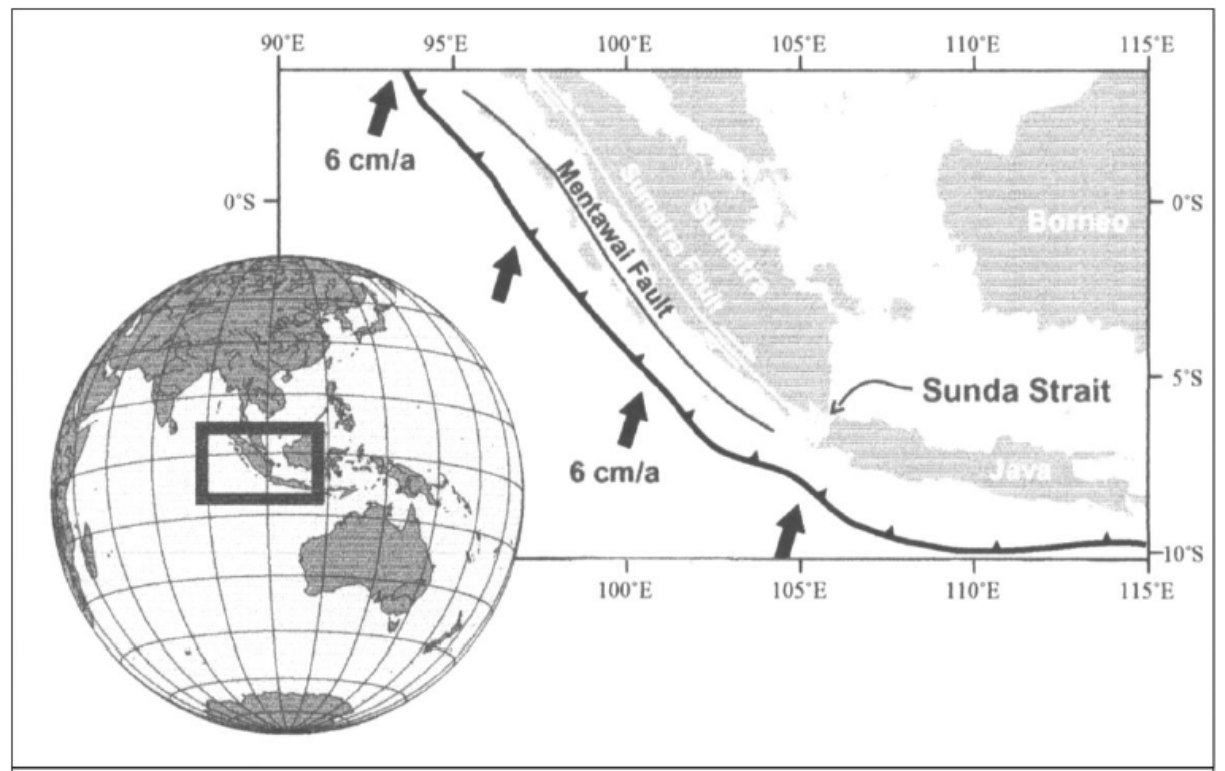

Gambar 1. Lokasi Selat Sunda dalam tatanan geologi Kepulauan Indonesia ( B. Mulyana, 2006).

Figure 1. Location of the Sunda Strait in the geology of the Indonesia Archipelago (B. Mulyana, 2006).

JURNAL KELAUTAN NASIONAL, Vol. 12, No 1, April 2017, Hal. 9-18 
minimal 7,0 Skala Richter. Salah satu upaya pencegahan tsunami adalah dengan reboisasi lahan mangrove. Sebuah studi mengungkapkan bahwa daerah yang ditanami mangrove mengalami kerusakan yang lebih sedikit dibanding area tanpa tutupan mangrove.

Berdasarkan bekal informasi ini, penulis sangat tertarik untuk melakukan studi pemodelan tsunami guna mengetahui penyebaran gelombang tsunami dari sumber gempa bumi terhadap Lebak dan kepulauannya, waktu yang diperlukan gelombang tsunami (travel time) dari sumber ke Lebak dan kepulauannya, dan ketinggian tsunami (run up) di Lebak dan kepulauannya serta guna memprediksi zona rawan tsunami untuk wilayah Lebak dan kepulauannya.

Penelitian ini bertujuan untuk sebagai bahan acuan bagi pemerintah daerah kabupaten Lebak untuk relokasi dan pengembangan pembangunan wilayah pantai. Hasil penelitian ini dapat sebagai bahan informasi tambahan bagi masyarakat sekitar dan pemda Lebak untuk melakukan mitigasi bencana di wilayah Lebak dan kepulauannya serta sebagai bahan referensi bagi semua pihak yang membutuhkan kajian tentang tsunami untuk wilayah Lebak dan kepulauannya.

\section{BAHAN DAN METODE}

\section{Data}

Data historis kejadian gempa bumi yang terjadi di sekitar wilayah Selat Sunda antara Pulau Sumatra dan Jawa yang diperoleh dari Badan Meteorologi Klimatologi dan Geofisika (BMKG). Sejarah kejadian gempa bumi ini memegang peranan penting dalam penyusunan skenario gempa bumi tektonik yang akan disimulasikan. Data parameter sesar gempa bumi di wilayah selatan Jawa diperoleh dari Global CMT Harvard (http://www.globalcmt.org).

Parameter sesar dari historis kejadian gempa bumi digunakan sebagai salah satu acuan dalam penyusunan skenario kasus terburuk kejadian gempa bumi pembangkit tsunami. Data batimetri selatan Jawa yang digunakan dalam penelitian ini berupa General Bathymetric Chart of the Oceans (GEBCO) yang diperoleh melalui British Oceanographic Data Centre (BODC). Data topografi di wilayah sekitar selatan Jawa menggunakan peta topografi digital dari BIG.

Skenario gempa bumi sebagai sumber tsunami yang terdapat di zona subduksi di selatan Jawa (Java trench) yang berpotensi menciptakan gempa yang dapat menyebabkan tsunami. Skenario gempa bumi yang digunakan dalam penelitian ini selengkapnya dapat diketahui dari Tabel 1,

Skenario gempa bumi pembangkit tsunami ini ditentukan berdasarkan historis gempa bumi besar yang pernah terjadi di zona subduksi wilayah selatan Jawa (Newcomb \& McCann, 1987). Nilai parameter sesar seperti magnitude, panjang (length), lebar (width) dan slip ditentukan berdasarkan tatanan tektonikdan teori hukum skala gempa bumi (scaling law of earthquakes) yang dikemukakan oleh Utsu (1970) dan Tatehata (1997). Peta Rupa Bumi Indonesia (RBI) di daerah penelitian diperoleh dari Badan Informasi Geospasial (BIG).

\section{Metode}

Gempa bumi pembangkit tsunami berupa data parameter gempa bumi tersebut diolah menggunakan perangkat lunak TUNAMI-N2 yang telah dimodifikasi untuk menghasilkan simulasi tinggi gelombang tsunami dan waktu gelombang datang di pantai menggunakan metode deterministik. Parameter skenario gempa bumi pembangkit tsunami selanjutnya diolah menggunakan perangkat lunak TUNAMI-N2. Perangkat lunak TUNAMI-N2 dibuat oleh Fumihiko Imamura dari Universitas Tohoku Jepang pada tahun 1995. TUNAMI-N2 merupakan model simulasi numerik tsunami yang menggunakan skema numerik leap-frog dalam menyelesaikan persamaan-persamaan dasar

Tabel 1. Skenario gempa bumi yang digunakan dalam penelitian

Table 1. The earthquake scenario used for the study

\begin{tabular}{|c|c|c|c|c|c|c|c|c|c|c|}
\hline Sesar & $\begin{array}{l}\text { Panjang } \\
(\mathbf{k m})\end{array}$ & $\begin{array}{l}\text { gebar } \\
(\mathrm{km})\end{array}$ & $\begin{array}{l}\text { lokasi sumber } \\
\left.\text { Lintang ( }{ }^{\circ} \mathrm{LS}\right)\end{array}$ & $\begin{array}{l}\text { gempabumi } \\
\text { Bujur }\left({ }^{\circ} \mathrm{BT}\right)\end{array}$ & $\begin{array}{l}\text { Mag } \\
(\mathbf{M w})\end{array}$ & $\begin{array}{l}\text { Strike } \\
\left(^{0}\right)\end{array}$ & $\begin{array}{l}\text { Dip } \\
\left(^{\circ}\right)\end{array}$ & $\begin{array}{l}\text { Rake } \\
\left({ }^{\circ}\right)\end{array}$ & $\begin{array}{l}\text { Slip } \\
\text { (m) }\end{array}$ & $\begin{array}{l}\text { Depth } \\
(\mathbf{k m})\end{array}$ \\
\hline Fault1 & 128 & 100 & 8,73 & 105,83 & 8,7 & 315 & 10 & 89 & 20 & 10 \\
\hline Fault2 & 115 & 100 & 8,05 & 104,87 & 8,7 & 281 & 10 & 100 & 20 & 10 \\
\hline Fault3 & 215 & 100 & 7,83 & 103,82 & 8,7 & 300 & 10 & 114 & 20 & 10 \\
\hline
\end{tabular}

Sumber : Historis gempa bumi BMKG, Utsu (1970) dan Tatehata (1997) 


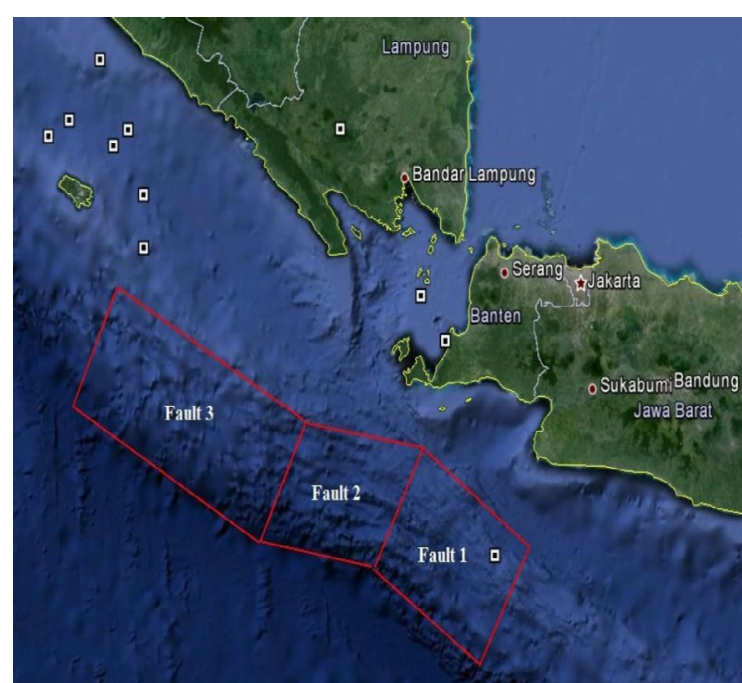

Gambar 2. Tata letak posisi sesar yang digunakan dalam penelitian

Figure 2. Cesar position in the study site

perambatan gelombang. TUNAMI sendiri merupakan singkatan dari Tohoku University's Numerical Analysis Model for Investigation of Near-field Tsunami. TUNAMI-N2 menggunakan teori persamaan gelombang panjang. Perhitungan gelombang di laut dalam hanya persamaan dengan suku linier yang dipakai, sementara di perairan dangkal hingga run-up, suku non-linier dilibatkan, lihat persamaan 1 hingga 6.

\section{Pemodelan Numerik Penjalaran Tsunami}

Estimasi dampak perambatan tsunami dapat dikuantifikasi menggunakan pemodelan numerik. Asumsi yang digunakan dalam pemodelan numerik ini adalah gelombang tsunami menjalar dalam bentuk gelombang panjang (ketinggian gelombang jauh lebih kecil dibandingkan dengan panjang gelombang), partikel air tidak memiliki percepatan vertikal dan tekanan air sama dengan tekanan akibat gaya gravitasi. Beberapa persamaan dasar dan pendekatan yang digunakan untuk memodelkan tsunami (Goto et al., 1997).

\section{Persamaan Kontinuitas (Continuity Equation)}

Persamaan Goto et al. (1997) ini didasarkan pada prinsip hukum kekekalan massa yang diterapkan pada fluida tak termampatkan. Persamaan ini secara sederhana dapat dituliskan sebagai berikut:

$$
\frac{\partial \eta}{\partial t}+\frac{\partial M}{\partial x}+\frac{\partial N}{\partial y}=0
$$

Keterangan:

$$
\mathrm{M}=\int_{-h}^{\eta} u d z=\bar{u}(h+\eta)
$$

Merupakan persamaan dinamika massa air (water discharge/flux) dalam arah $\mathrm{x}$

$\mathrm{N}=\int_{-h}^{\eta} v d z=\bar{v}(h+\eta)$

Merupakan persamaan dinamika massa air (water discharge/flux) dalam arah y

Persamaan Momentum

Arah X :

$\frac{\partial N}{\partial t}+\frac{\partial}{\partial x}\left(\frac{M N}{D} \quad \frac{\partial}{\partial y}\left(\frac{N^{2}}{D}\right)+g D \frac{\partial \eta}{\partial y}+\frac{g n^{2}}{D} \frac{D^{7 / 3}}{M^{2}+N^{2}}=0\right.$

Arah Y

$\frac{\partial N}{\partial t}+\frac{\partial}{\partial x}\left(\frac{M^{2}}{D} \quad \frac{\partial}{\partial y}\left(\frac{M N}{D}\right)+g D \frac{\partial \eta}{\partial y}+\frac{g n^{2}}{D^{2} / 3} M \sqrt{M^{2}+N^{2}}=0\right.$

Keterangan:

$\mathrm{M}=\int_{-h}^{\eta} u d z$

merupakan debit dalam arah $\mathrm{x}$ $\left(\mathrm{m}^{2} /\right.$ detik $)$

$\mathrm{N}=\int_{-h}^{\eta} v d z$ merupakan debit dalam arah y $\left(\mathrm{m}^{2} /\right.$ detik $)$

$D=(h+\eta)$ merupakan total kedalaman air dari dasar sampai ke permukaan air sesaat $(\mathrm{m})$

$\mathrm{h}=$ kedalaman air dari dasar laut ke mean sea level(m)

$=$ ketinggian air dari permukaan atau elevasi sesaat (m)

$\mathrm{g} \quad=$ percepatan gravitasi

$\mathrm{n} \quad=$ koefisien kekasaran (Manning roughness)

$\mathrm{t} \quad=$ waktu (detik)

Persamaan Gesekan Dasar

Arah x: $\frac{\tau_{x}}{\rho}=\frac{f n^{2}}{D^{7 / 3}} M \sqrt{M^{2}+N^{2}}$

Arah y: $\frac{\tau_{y}}{\rho}=\frac{f n^{2}}{D^{7 / 3}} M \sqrt{M^{2}+N^{2}}$

Hubungan antara koefisien gesekan $\mathrm{f}$ dan koefisien kekasaran (Manning's roughness) dengan nilai 0,025 (nilainya constant homogeny) dinyatakan sebagai berikut:

$$
n=\sqrt{\frac{f D^{1 / g}}{2 g}}
$$

Nilai koefisien gesekan dasar (n) dipilih berdasarkan kondisi dasar perairan. 


\section{Deformasi Patahan dan Parameter Patahan}

Pemodelan tsunami memerlukan adanya input gelombang berdasarkan penentuan parameter patahannya. Parameter-parameter sesar seperti panjang (L) dan lebar sesar (W), energi dan magnitud, kedalaman pusat gempa (H), slip (D) dan mekanisme fokus (strike $(\theta)$, dip $(\delta)$ dan sudut slip $(\gamma)$ ) adalah parameter-parameter yang utama dari sumber gempa (Gambar 3), yang berfungsi untuk pembentukan awal gelombang tsunami sebelum tsunami itu menjalar.

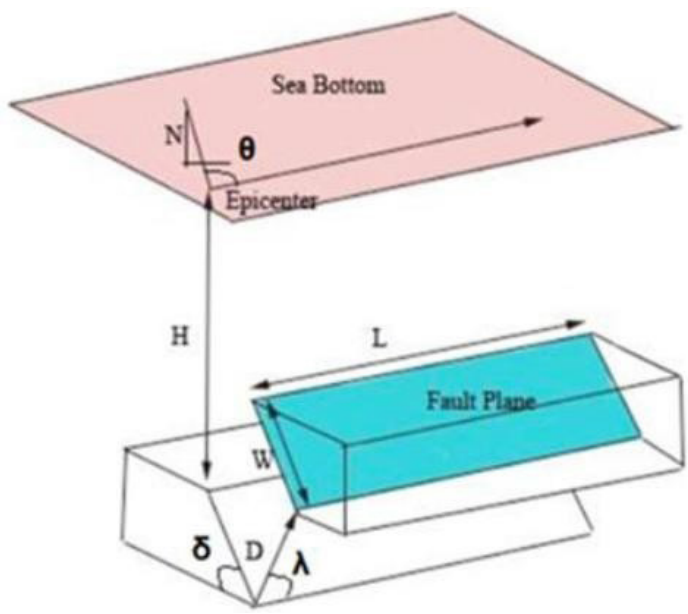

Gambar 3. Parameter - parameter Sesar (Imamura, 2006).

Figure 1. Parameters of deformation (Imamura, 2006).

\section{HASIL DAN PEMBAHASAN}

\section{Seismisitas di Kabupaten Lebak Banten}

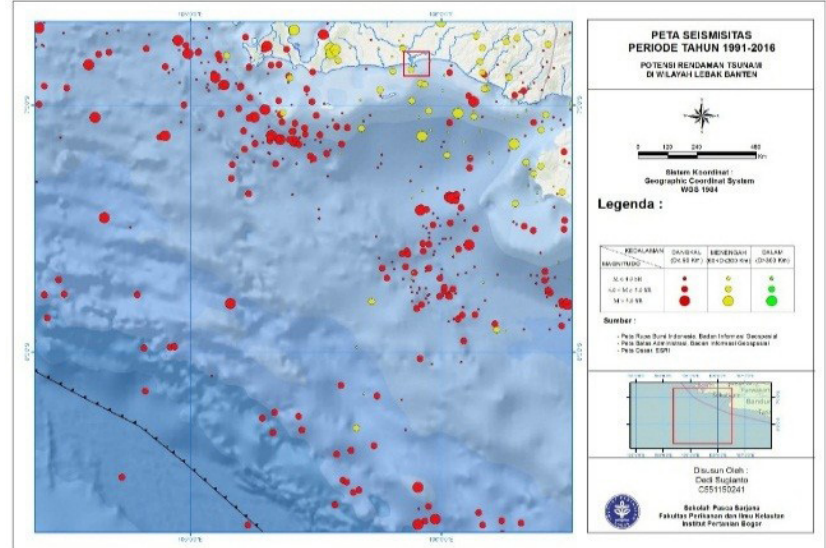

Gambar 4. Peta Seismisitas Kabupaten Lebak Figure 4. Seismicity map of Lebak

Berdasarkan data seismisitas yang sudah di relokasi dari BMKG tahun 1991-2016 untuk wilayah Kabupaten Lebak dan sekitarnya diperoleh gambaran bahwa tingkat frekuensi gempa bumi dengan kekuatan lebih dari 4 Skala Richter sangat tinggi dan sumber nya menyebar hampir merata baik di darat maupun di laut (Gambar 7). Pada gambar 6 juga dapat dilihat bahwa Kabupaten Lebak yang terletak pada bagian tepi selatan Sunda arc yang merupakandaerah patahan lempeng. Daerah-daerah tersebut sebagai zona seismik aktif yang merupakan sumber gempa bumi dan tsunami.

Berdasarkan analisis seismisitas, dapat disimpulkan bahwa Kabupaten Lebak merupakan daerah yang berpotensi sangat tinggi dilanda gempa bumi dan tsunami sehingga upaya penanggulangan (mitigasi) sangat diperlukan. Salah satu langkah mitigasi untuk mengurangi dampak negatif.

\section{Validasi Luaran TUNAMI-N2}

Sebelum dilakukan simulasi terhadap skenario gempa bumi pembangkit tsunami di wilayah Lebak Banten dan sekitarnya, TUNAMI-N2 digunakan untuk mensimulasikan proses terjadinya tsunami yang melanda Pangandaran. Hal ini dilakukan untuk memberikan gambaran validitas hasil simulasi jika dibandingkan dengan kejadian sebenarnya. Validasi dilakukan dengan menggunakan parameter gempa yang pernah terjadi sebelumnya. Tinggi tsunami Pangandaran digunakan untuk mengecek apakah hasil keluaran model ini sama dengan hasil pengamatan di lapangan. Simulasi dilakukan menggunakan parameter gempa yang menyebabkan tsunami pangandaran pada tanggal 17 Juli 2006 dengan pusat gempa bumi terletak di $10,28{ }^{\circ} \mathrm{LS}$ dan $107,78{ }^{\circ} \mathrm{BT}$. Hasil keluaran model TUNAMI-N2 yang dihasilkan memiliki kesamaan dengan hasil yang pernah dilakukan sebelumnya oleh penelitian sebelumnya (Rahmawan, 2012), seperti yang ditunjukkan pada Gambar 8 .

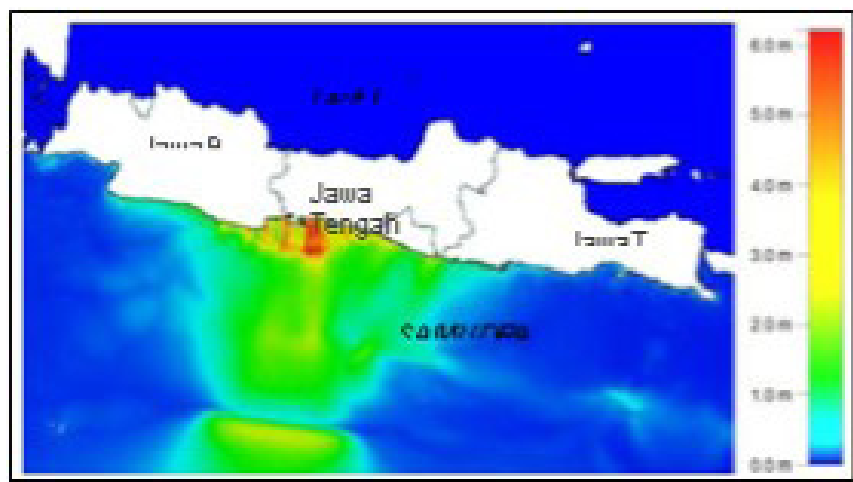

Gambar 5. Pola tinggi maksimum tsunami Pangandaran (Sumber : Rahmawan, 2012)

Figure 5. The maximum height pattern of Pangandaran tsunami (Source : Rahmawan, 2012). 
Hasil keluaran TUNAMI-N2 tersebut selanjutnya dibandingkan dengan hasil survei ketinggian gelombang tsunami maksimum yang dilakukan oleh tim survei BMKG tahun 2006 di sepanjang pantai selatan Jawa. Perbandingan hasil tersebut dapat diketahui melalui Gambar 9, dengan nilai RMSE 0,98.

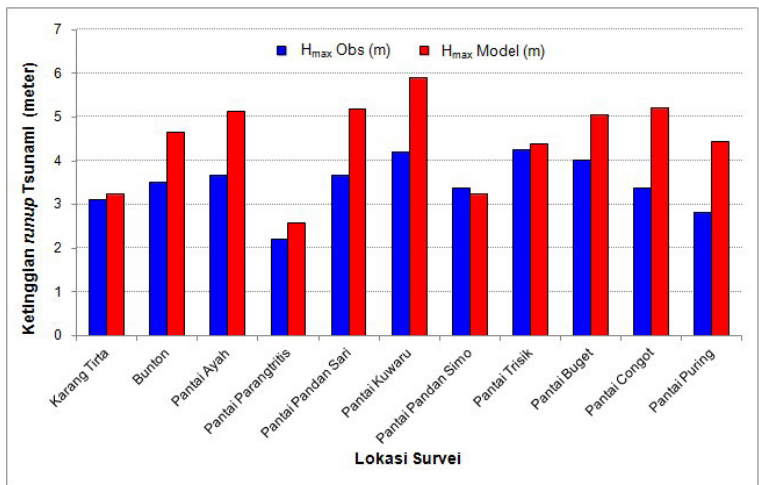

Gambar 6. Perbandingan tinggi gelombang tsunami hasil survei dan keluaran model TUNAMI-N2.

Figure 6. Tsunami wave height comparison between survey results and output of model TUNAMI-N2.

\section{Keluaran Model TUNAMI-N2}

Model TUNAMI-N2 dijalankan melalui proses nesting menjadi empat wilayah dalam menganalisis potensi rendaman tsunami. Pembagian wilayah dimaksudkan untuk optimalisasi perhitungan dan memperoleh hasil simulasi dengan resolusi yang lebih tinggi pada wilayah yang menjadi fokus penelitian. Tata letak wilayah tersebut secara umum dapat diketahui dari Gambar 7.
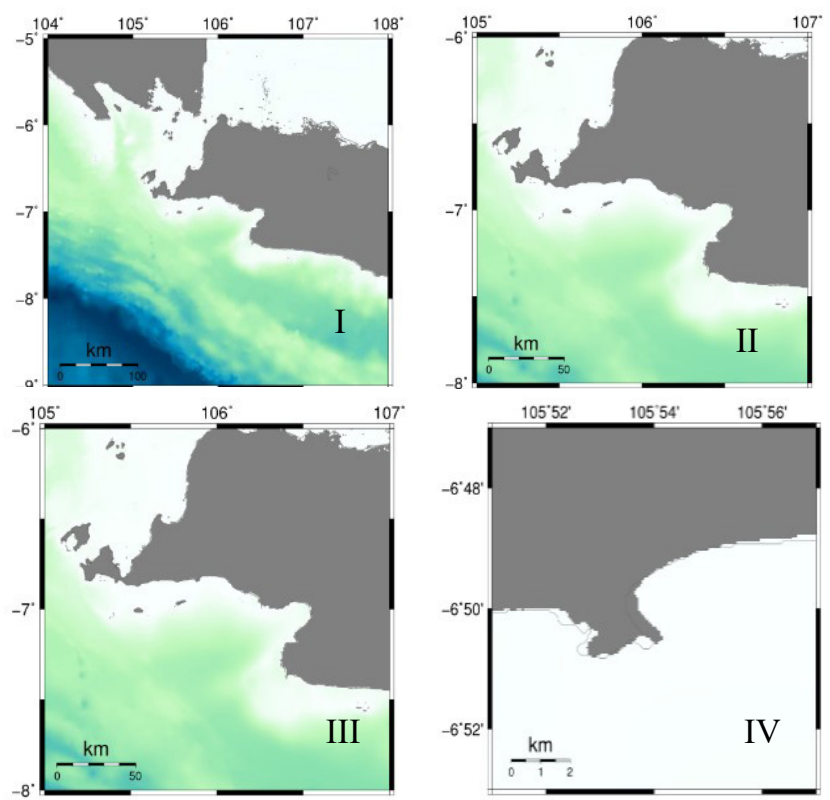

Gambar 7. Tata letak nested model.

Figure 7. The layout of nested model.
Proses simulasi pemodelan gelombang tsunami akibat gempa bumi di Palung Jawa dilakukan dengan menggunakan empat wilayah pemodelan atau yang biasa dikenal sebagai nested model. Interval grid pada nested model dihitung dari syarat kestabilan dan konsistensi dalam memperoleh solusi metode numerik di TUNAMI-N2, sehingga masing-masing wilayah memiliki resolusi yang berbeda. Interval grid yang digunakan untuk masing - masing wilayah adalah 1.850 meter untuk wilayah 1 , interval grid 616 meter untuk wilayah 2, interval grid 205 meter untuk wilayah 3 dan interval grid 68 meter untuk wilayah 4 lihat Gambar 7. Pemodelan gelombang tsunami dijalankan selama 2 jam (7.200 detik) dengan interval waktu gambaran sesaat (snapshoot) setiap 1 menit.

\section{Simulasi Pola Ketinggian Gelombang Tsunami di Laut dan Darat(Run-up)}

Wilayah pertama untuk simulasi ketinggian tsunami (Run-up) meliputi wilayah Sumatra bagian selatan, Lampung dan Jawa bagian barat; wilayah kedua meliputi wilayah Lampung, Banten dan Jawa Barat; wilayah ketiga meliputi wilayah Lebak Banten dan Jawa Barat, Sedangkan untuk wilayah keempat lebih fokus ke wilayah pesisir pantai Lebak yaitu pantai Bagedur dan sekitarnya. Gambaran umum tinggi gelombang tsunami sesaat (menit ke-0) setelah gempa bumi pembangkit tsunami terjadi sesuai skenario yang digunakan dapat diketahui dari Gambar 8.
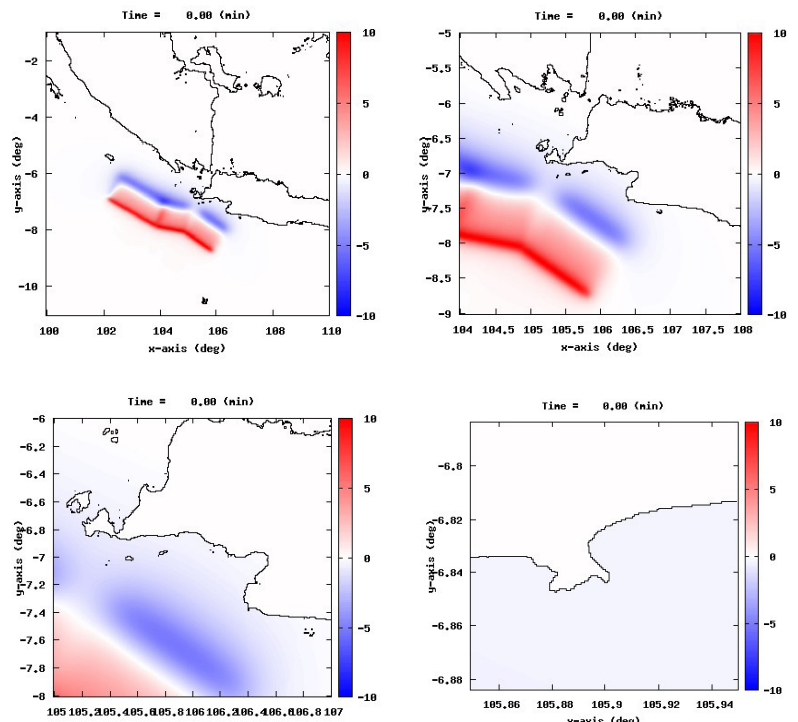

Gambar 8. Pola ketinggian gelombang tsunami sesaat

(menit ke 0) setelah terjadi gempa bumi pembangkit tsunami di wilayah 1 (atas), wilayah 2 (bawah), wilayah 3 (kiri bawah) dan wilayah 4 (kanan bawah).

Figure 8. Temporal wave height pattern (minute 0) after earthquake in region 1 (top), region 2 (bottom), region 3 (lower left) and region 4 (lower right). 
Berdasarkan hasil simulasi penjalaran gelombang tsunami pada gambar 9 tersebut dapat diketahui bahwa skenario parameter gempa bumi pembangkit tsunami menghasilkan fase ketinggian yang berbeda antara wilayah di sebelah baratdaya dan timur laut pusat gempa bumi. Perairan di bagian timurlaut pusat gempa bumi mengalami penurunan ketinggian dan di bagian baratdaya pusat gempa bumi mangalami kenaikan permukaan air laut sesaat setelah terjadi gempa bumi. Meskipun demikian, penurunan tinggi permukaan air laut ini masih belum sampai teramati di wilayah pesisir Lebak Banten maupun pesisir.

Gambaran sesaat (snapshoot) pola simulasi perambatan gelombang tsunami pada menit ke-15 dapat diketahui pada Gambar 9. Pada selang waktu ini, indikasi gelombang tsunami berupa permukaan air laut yang rendah (surut) mulai mencapai wilayah pantai di

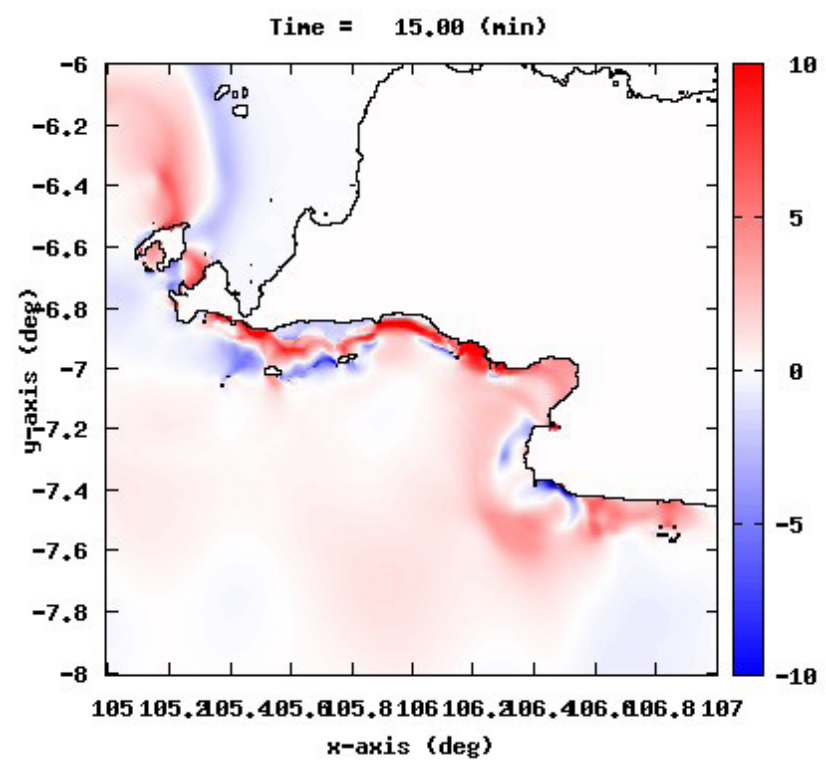

Gambar 9. Gambaran sesaat pola ketinggian gelombang tsunami pada menit ke-15 setelah terjadi gempabumi pembangkit tsunami di wilayah 3 .

Figure 9. The momentary picture of the tsunami wave height pattern at the 15th minute after the earthquake in region 3.

sebelah utara Taman Nasional Ujung Kulon dan Pesisir Pantai Lebak, diikuti dengan naiknya permukaan air laut. Bahkan gelombang tsunami dengan ketinggian mencapai 5 hingga 10 meter telah ada yang mencapai di beberapa wilayah sebelah selatan Sumatera dan Pesisir Teluk Ujung Genteng dan sekitarnya. Meskipun demikian, kondisi permukaan air laut rendah (surut) secara tiba-tiba masih terjadi di wilayah Pesisir Pantai Bagedur. Hal ini tentu dapat dijadikan sebagai salah satu tanda awal (precursor) akan terjadinya gelombang tsunami.

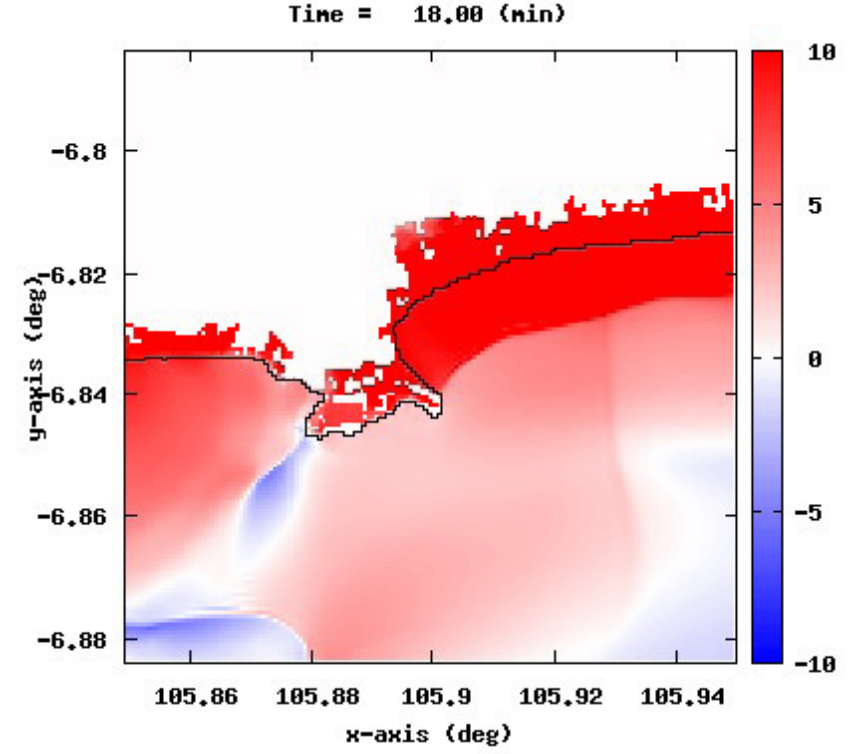

Gambar 10. Gambaran sesaat pola ketinggian gelombang tsunami pada menit ke18 setelah terjadi gempabumi pembangkit tsunami di wilayah 4 .

Figure 10. Momentary picture of tsunami wave height pattern at 18 th minute after earthquake in region 4.

Pola gelombang tsunami yang terbentuk pertama kali setelah simulasi dilakukan umumnya mengikuti bentuk skenario parameter sesar yang diberikan. Proses perambatan gelombang tsunami berikutnya di wilayah Samudra Hindia selatan Jawa didominasi pola perambatan ke arah timur laut dan baratdaya menjauhi pusat gempa bumi.

Ketinggian gelombang tsunami di laut yang dapat terjadi akibat gempa bumi di celah kegempaan sekitar Palung Jawa umumnya mengikuti pola batimetri kedalaman laut saat terdapat di wilayah perairan dangkal dan dibelokkan oleh pola garis pantai. Karakteristik tsunami yang merambat dan mencapai wilayah ini umumnya didahului dengan fase negatif yang ditandai dengan turunnya permukaan air laut. Setelah fase negatif, beberapa menit kemudian terjadi fase positif yang ditandai dengan mulai bertambahnya ketinggian air laut secara signifikan hingga melebihi ketinggian muka air laut rata-ratanya (mean sea level)

Analisis kemiringan lereng (slope) dilakukan untuk mengetahui karakteristik kemiringan wilayah pesisir Lebak Banten seperti yang ditunjukkan oleh Gambar 3. Wilayah pesisir ini umumnya memiliki kemiringan datar sampai dengan hampir datar (slope 0 - 2\%) dan sangat landai (slope 2 - 8\%). Meskipun demikian, terdapat wilayah dengan kemiringan landai (slope 8 - 14\%) dan agak curam (slope 14 - $20 \%$ ) di bagian 
bawah sebagai representasi permukiman dan pesisir pantai yang langsung berbatasan dengan laut. Wilayah lainnya didominasi oleh sangat landai (slope 8 - 14\%) dan sebagian kecil lainnya memiliki kemiringan landai (slope 8 - 14\%). Kondisi ini mengakibatkan potensi rendaman tsunami di pesisir Lebak Banten.

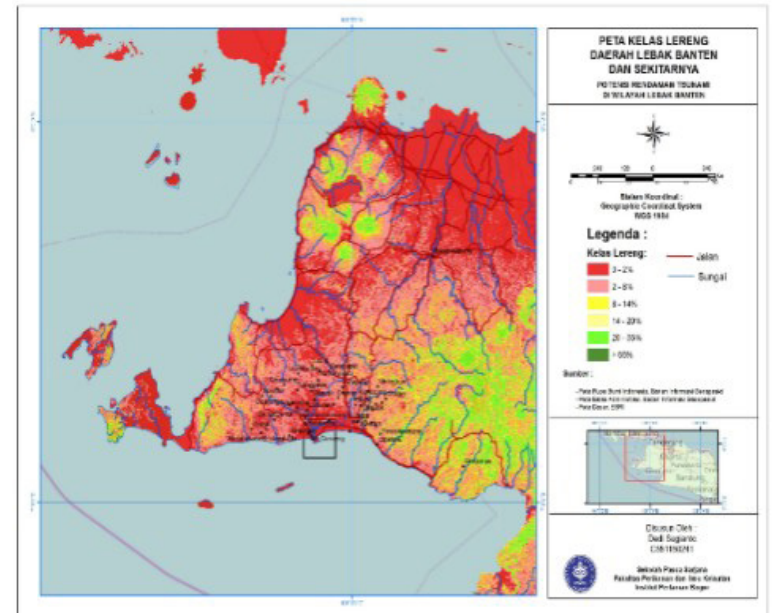

Gambar 11. Peta kemiringan lereng daerah Lebak Banten. Figure 11. Map of the Lebak Banten coastal slopes.

\section{Simulasi Potensi PenggenanganTsunami}

Hasil simulasi ketinggian gelombang tsunami maksimum wilayah pesisir Pantai Bagedur Lebak dan sekitarnya memiliki ketinggian kisaran 16 hingga 20 meter dapat dilihat pada Gambar 12. Ketinggian gelombang tsunami ini berpotensi menimbulkan genangan jika didukung oleh bentuk pantai yang landai. Simulasi waktu tempuh yang diperlukan oleh gelombang tsunami pertama hingga mencapai wilayah pesisir Lebak dilakukan untuk mengetahui seberapa lama waktu yang dimiliki oleh masyarakat untuk melakukan antisipasi menghadapi tsunami.

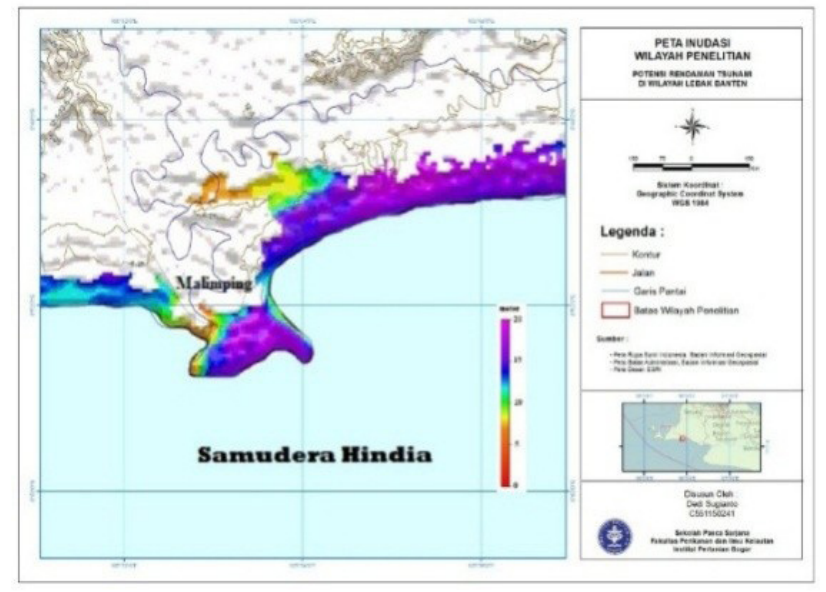

Gambar 12. Peta genangan dan ketinggian gelombang tsunami maksimum di sekitar wilayah penelitian

Figure 12. Maximum inundation and tsunami wave heights in research location.

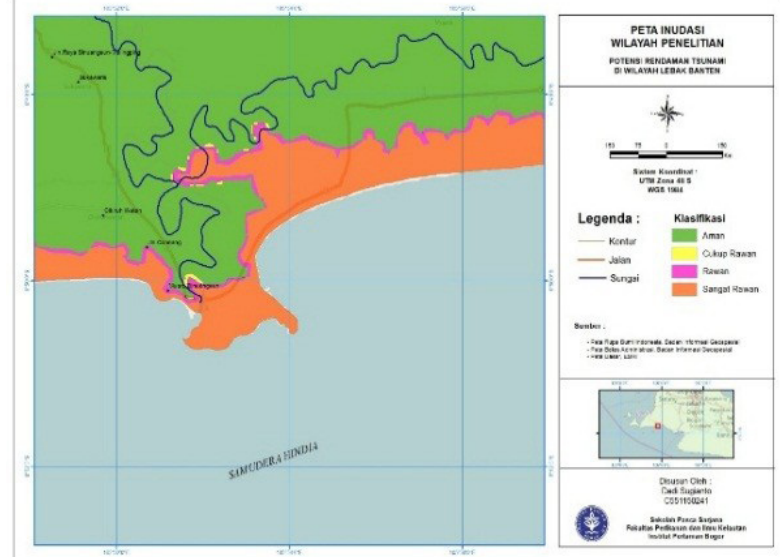

Gambar 13. Peta tingkat kerawanan.

Figure 13. Map of the vulnerability level.

Dari hasil tumpang susun (overlay) peta genangan dan peta kemiringan lereng diperoleh peta tingkat kerawanan seperti terlihat pada (Gambar 13) Berdasarkan pada peta ini wilayah yang rawan terdapat di sepanjang pesisir Malingping Lebak.

\section{Upaya Mitigasi}

Tsunami yang terjadi di Lebak dapat direduksi dengan menanam sabukhijau (green belt). Kapasitas sabuk hijau dalam mereduksi tsunami tidak efektif untuk tsunami dengan ketinggian lebih dari $5 \mathrm{~m}$ (Shuto, 1987). Salah satu upaya agar sabuk pantai dapat berperan dalam mereduksi tsunami, maka diperlukan ketebalan yang cukup agar dapat bekerja secara efektif. Berdasarkan pada pengamatan lapangan, kondisi wilayah pesisir merupakan wilayah permukiman atau dibangun untuk kepentingan lainnya (industri, perkotaan, perumahan, pariwisata, transportasi, perikanan dan pertanian), sehingga diperlukan kebijakan pemindahan kegiatan di pesisir dengan cara persuasif serta perencanaan dan pengelolaan akitivitas di pesisir dengan baik. Sesuai dengan Pasal 21 UU No. 27/2007 dan Pasal 56 ayat 1 PP No. 26/2008 tentang kawasan setback atau sempadan pantai, bahwa sempadan pantai harus berjarak paling pendek 100 (seratus) meter dari garis pantai.

Berdasarkan simulasi tinggi gelombang datang (run up) $20 \mathrm{~m}$, maka ekosistem mangrove tidak cukup untuk meredam sebaran genangan, perlu pula diperkuat dengan vegetasi pantai lainnya dan struktur bangunan pantai yang kokoh untuk mereduksi genangan. Upaya lain untuk mitigasi dapat berupa pemetaan kawasan rawan tsunami dengan skala yang cukup memadai, pembuatan jalur dan tempat evakuasi sampai dengan sistem peringatan dini bencana tsunami. 


\section{KESIMPULAN DAN SARAN}

Ketinggian gelombang tsunami di darat (run-up) akibat tsunami yang terjadi dari gempa bumi di Wilayah Lebak umumnya berkisar antara 15 hingga 20 meter dengan sebaran mengikuti pola topografi ketinggian wilayah. Waktu tempuh yang diperlukan oleh gelombang tsunami pertama hingga mencapai wilayah pesisir Lebak berkisar antara 15 hingga 17 menit dengan sebaran wilayah yang lebih dekat dengan pusat gempa bumi sumber tsunami akan mengalami tsunami lebih dahulu. Potensi rendaman wilayah pesisir Lebak pada umumnya termasuk pada kategori sangat berbahaya mengingat tinggi maksimum dapat mencapai lebih dari 3 meter dari permukaan laut dan jarak maksimum rendaman mencapai $1,7 \mathrm{~km}$ dari garis pantai dengan total luas rendaman 1271,34 ha.

\section{UCAPAN TERIMA KASIH}

Penulis mengucapkan terima kasih kepada BMKG Pusat Gempa Bumi dan Tsunami yang telah menyediakan data gempa di wilayah Lebak Banten.

\section{DAFTAR PUSTAKA}

Aydan, O.(2008). Seismic and Tsunami Hazard Potentials in Indonesia with a special emphasis on Sumatra Island. Journal of The School of Marine Science and Technology, Tokai University, Vol.6, No.3, pp.19-38.

Bryant, E. (2008).Tsunami The Underrated Hazard (Second Edition). Springer-Praxis Books In Geophysical Sciences. ISBN 978-3-540- 74273-9 Springer Berlin Heidelberg New York.

Dao, M.H., Tkalich, P., Chan, E.S., \& Megawati, K. (2008). Tsunami propagation scenarios in the South China Sea. Journal of Asian Earth Sciences 36.

Diposaptono, S., \& Budiman. (2006). Tsunami"Buku Ilmiah Populer, Jakarta.

Goto, C., Ogawa, Y., Shuto, N., \& Imamura, F. (1997). Numerical Method of Tsunami Simulation with the Leap-Frog Scheme (IUGG/IOC Time Project). IOC Manual. UNESCO, No. 35.

Imamura, F. (2006). Tsunami Modelling Manual, Disaster Control Reasearch Center, Tohoku University, Senday, Japan.

IOC. (2006). Tsunami Glossary. Intergovernmental Oceanographic Commission 2008. Paris, UNESCO. IOC Technical Series, 85.

Historis Gempa bumi BMKG. (2012). Skenario gempa bumi sebagai sumber tsunami di zona subduksi selatan Jawa. Pusat Gempa Bumi dan Tsunami Jakarta.

Kanamori, H. (1972). Mechanism of tsunami earthquake. Physic of the Earth and Planetary Interiors 6:246-259.

Latief, H. (2000). Tsunami Modelling, Risk Assesment, and Mitigation, Pusat Penelitian Kelautan, Institut Teknologi Bandung.

Latief, H., H. Sunendar, Yuhsananta. P., \& E. Riawan. (2006). Pemodelan dan Pemetaan Rendaman Tsunami Serta Kajian Risiko Bencana Tsunami Kota Padang, PPKPL, ITB.

LIPI/ DLR/ UNU-EHS. (2011). Guideline for Tsunami Risk Assessment in Indonesia: Scientific Proposal for Practitioner and End Users. Provided by the Indonesian - German Working Group on Tsunami Risk Assessment. 132p.

Malod, J.A., Karta, K., Beslier, M.O., \& Zen, M.T. (1995). From Normal to Oblique Subduction: Tectonic Relationships Between Java and Sumatra. Journal of Southeast Asian Earth Sciences, 12 (1-2), h.85- 93.

Mulyana, B. (2006). Extension Tektonik Selat Sunda. Bulletin of Scientific Contribution, Volume 4, Nomor 2, Agustus 2006 : 137-145.

Newcomb, K.R., \& McCann, W.R. (1987). Seismic history and seismotectonics of the Sunda Arc. Journal of Geophysical Research, vol 92 No. B1 10 Januari 1987: 421-439

Pemerintah Republik Indonesia. (2007). Undang Undang No. 27 Tahun 2007 Tentang Pengelolaan Wilayah Pesisir dan Pulau-pulau Kecil.

Pemerintah Republik Indonesia. (2008). Peraturan Pemerintah No. 26 Tahun 2008 Tentang Penataan Ruang dan Rencana Tata Ruang Wilayah Nasional.

Philip, L.F., Harr, Yeh., \& Costas Synolakis. (2008). Advanced Numerical Models for Simulating Tsunami Waves and Run Up, World scientific.

Purbani, D. (2012). Aplikasi Penginderaan Jauh dan Sistem Informasi Geografi untuk Mengetahui Pola Sebaran Genangan Tsunami dan Tingkat Kerentanan Studi Kasus: Pulau Weh. Jurnal Segara Vol. 8 No. 1 Agustus 2012: 35-44.

Rahmawan, SH. (2012). Studi Potensi Bahaya Tsunami di Selatan Jawa. Tugas Akhir S1 Fakultas Ilmu dan Teknologi Kebumian. ITB. Bandung.

Rudyanto, A. (2010). Pemodelan Tsunami Sebagai Bahan Mitigasi Bencana Studi Kasus Sumenep dan Kepulauannya. Jurnal Neutrino Vol.2.

Satake, Kenji.(2006). Tsunami and Earthquake, Geological Survey of Japan, National Institut of Advance Industrial Science and Technology, IISEE (International Institute of Seismology and Earthquake Enginering), Tsukuba.

Shuto, N. (1987). The Effectiveness and Limit of Tsunami Control Forests. Coast. Eng. Japan 30 (1): 143-153.

Soleman, M.Khifni., Nurcahyani, Fitri., Munajati, Sri Lestari. (2012). Pemetaan Multirawan Bencana di Provinsi Banten. Globe Volume 14 No. 1 Juni 2012 : 46 - 59.

Tatehata, H. (1997). The New Tsunami Warning System of the Japan Meteorological Agency in "Perspectives on Tsunami Hazard Reduction (edited by G. Hebenstreit)". Kluwer Academic Publishers. Dordrecht, The Netherlands.

Utsu, T. (1970). Aftershocks and earthquake statistics 
(II) - Further investigation of aftershocks and other earthquake sequences based on a new classification of earthquake sequences. J. Fac. Sci. Hokkaido Univ., Ser. VII, 3, 197-266.

Trimulyani, L. (2014). Potensi Penggenangan Tsunami akibat Gempa bumi di wilayah Palung Jawa (Kasus Pantai dan Pesisir Pelabuhan Ratu). Tugas Akhir S2 Geografi. UGM. Yogyakarta.

UNESCO-IOC. (2006). Tsunami Glossary",IOC Information document No.1221.Paris. www.shoa.cl.

V. Santiago Fandino , H.Tanaka, M. Spiske. (2016). Tsunamis and Earthquakes in Coastal Environments, coastal library, Japan.

Yanagisawa, H. (2012). Numerical Simulation of Tsunami and its Application. Lecture Note. IISEE, Tsukuba, Japan. 